\title{
Implementasi Prototype Sistem Home security dengan Pemanfaatan Kode Akses berbasis Arduino Mega
}

\author{
DECY NATALIANA, SABAT ANWARI, MUHAMMAD SYAHRUL AKBAR \\ Teknik Elektro Institut Teknologi Nasional (ITENAS) Bandung \\ Email: decy@itenas.ac.id
}

\begin{abstract}
ABSTRAK
Sistem home security adalah suatu sistem yang dirancang sedemikian rupa yang digunakan untuk mengamankan sebuah perangkat hardware atau software. Home security yang dirancang ini berupa prototype yang terdiri dari input dan output. Input terdiri dari limit switch, motion sensor, Keypad 3x4. Output yang dirancang terdiri dari hardware dan software. Hardware berupa Lcd 16x2, LED, buzzer dan motor servo, sedangkan untuk software memberikan perintah ataupun program ke arduino mega yang untuk ditampilkan ke PC. Sistem home security yang telah direalisasikan mampu mengaktifkan buzzer yang berfungsi sebagai alarm rumah ketika melakukan kesalahan dalam memasukkan akses kode, dan akan menonaktifkan buzzer dan limit switch ketika akses kode yang dimasukkan benar. Saat berada didalam ruangan motion sensor detection akan langsung membaca pergerakan sehingga lampu yang berupa led akan menyala kemudian motor servo akan bergerak kearah masing-masing ruangan dan kamera merekam yang terjadi pada masing-masing ruangan dengan mengikuti arah motor servo yang telah di program 00,90 dan $180^{\circ}$.
\end{abstract}

Kata kunci: Security Sistem, Arduino Mega, Motion Detection, Limit Switch, Motor Servo.

\section{ABSTRACT}

Home security sistem is a sistem that is designed in a way that is used to secure a piece of hardware or software. Home security is a prototype designed consisting of input and output. Input consists of a limit switch, motion sensor, $3 \times 4$ Keypad. Output designed consists of hardware and software. Hardware such as LCd 16x2, LED, buzzer and servo motors, while the software gives the command or program to arduino mega were to be shown to the PC. Home security sistem that has been realized is able to activate an alarm buzzer which serves as the home when it made a mistake in entering the access code, and will disable the buzzer and the limit switch when access code is entered correctly. When being in the room sensor motion detection will directly read the movement so that the lights in the form of LED will light then the servo motor will move toward each room and a kamera to record what happened in each room to follow the direction of servo motors that have been in the program $0^{\circ}, 90^{\circ}$ and $180^{\circ}$.

Keywords : Security Sistem, Arduino Mega, Motion Detection, Limit Switch, Servo Motor 


\section{PENDAHULUAN}

Dampak dari kota metropolitan salah satunya adalah tingkat kejahatan yang kian meningkat, maka diperlukkan sistem keamanan rumah. Sistem keamanan pada rumah saat ini banyak yang menerapkan teknologi sistem home security untuk keamanan dirumah (Subari, 2015). Dengan sistem home security, keamanan rumah akan diatur sedemikian rupa sehingga meningkatkan keamanan serta kenyamanan (Doni, 2011), oleh karena itu sistem home security akan dirancang dan direalisasikan pada penelitian ini. Pada security sistem, alarm akan aktif apabila seseorang masuk kedalam rumah tanpa memasukkan kode akses, dan jika memasukkan kode akses benar maka alarm tidak aktif. Dalam penelitian ini sistem home security yang akan dirancang dan direalisasikan dengan menggunakan modul arduino mega. Modul ini dipilih karena penggunaaanya yang mudah serta memiliki jumlah pin yang banyak, sehingga sistem home security dapat di implementasikan dengan kontroller jenis arduino mega. Oleh karena itu, penulis mengimplementasikan sistem home security dengan pembaharuan yang semula rumah tidak menggunakan sistem home security menjadi rumah yang memiliki sistem home security dengan akses kode yang telah dirancang. Berikut spesifikasi alat sistem home security yang dirancang dan direalisasikan harus mampu melakukan beberapa proses yaitu:

1. Dapat mengetahui pergerakan manusia sehingga menyalakan LED secara otomatis sesuai dengan ruangan yang terdeteksi dengan adanya pergerakan manusia tersebut.

2. Dapat menghidupkan alarm yang berupa buzzer saat seseorang masuk tanpa memasukka kode pengamanan yang telah deprogram terlebih dahulu.

3. Menampilkan video kedalam komputer saat adanya pergerakan manusia sesuai dengan pergerakkan manusia tersebut ke suatu ruangan.

4. Mampu menghidupkan lampu berupa LED secara otomatis sesuai dengan pencahayaan.

Skematik kode akses sistem home security dapat dilihat pada Gambar 1.

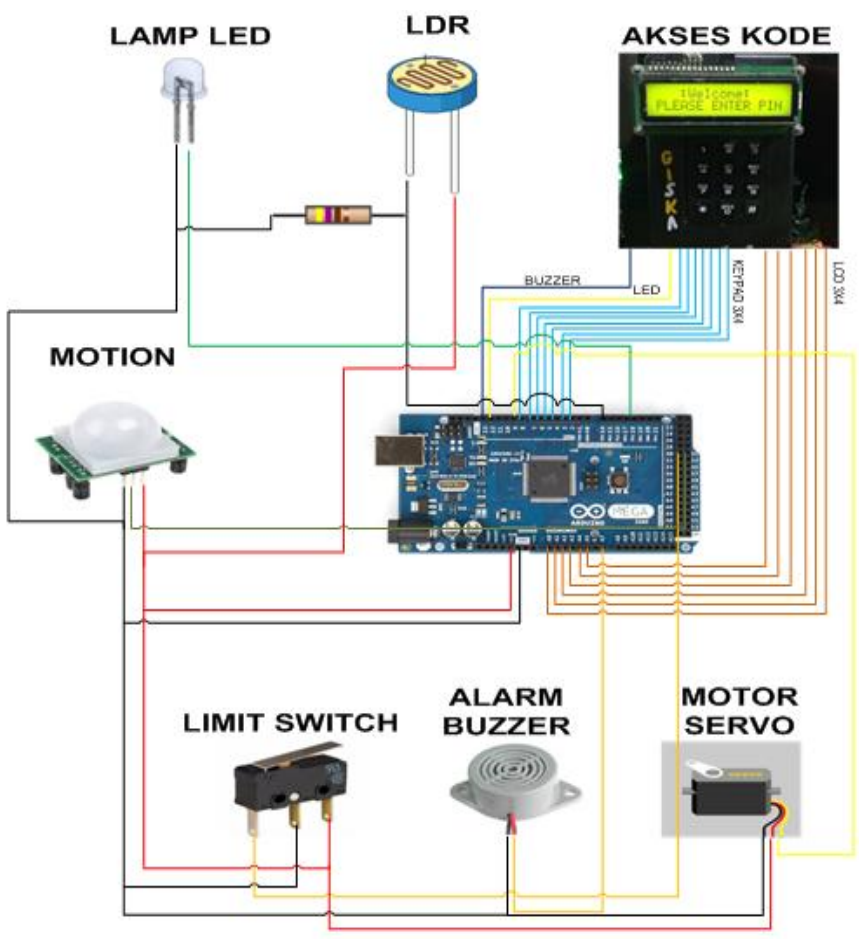

Gambar 1. Skematik kode akses sistem home security 
Menurut Ardian, menjelaskan sistem home terdiri dari keamanan, kenyamanan dan penghematan energy harus mempertimbangkan aspek efisiensi energi dan harus dapat diawasi. Dalam penelitiannya telah dirancang dan dibuat suatu sistem yang dapat melakukan usaha efisiensi tersebut melalui pengawasan penggunaan energy listrik. Hasil dari perancangan sistem ini dapat melakukan pengawasan, perekaman, pembatasan, penggunaan daya listrik dan mengatur pencahayaan di dalam ruangan berdasarkan jumlah penghuni ruangan dan intensitas cahaya luar (Ardian, 2007).

Menurut murisa, menjelaskan pada jurnal reka elkomika bahwa webcam pada umumnya digunakan sebagai media komunikasi dunia maya. Namun pada model sistem monitoring yang direalisasikan, penulis menggunakan webcam sebagai sensor yang mengganti indera penglihatan untuk melakukan monitoring di dalam ruangan. Dalam melakukan monitoring, webcam dapat digerakkan secara horizontal dan vertikal menggunakan 2 buah motor servo yang dikendalikan oleh mikrokontroller Atmega 16. Pada model sistem ini, dikembangkan pula program motion detection untuk mendeteksi adanya pergerakan di dalam ruangan. Jika terjadi pergerakan, maka tampilan gambar dari webcam akan direkam pada PC, dan mikrokontroler akan mengaktifkan buzzer. Karena webcam memiliki keterbatasan pencahayaan ketika ruangan gelap, maka dilakukan penambahan modul infra merah yang dilengkapi sensor LDR. Dengan modul ini, pergerakkan di dalam ruangan yang gelap dapat terdeteksi sejauh $6 \mathrm{~m}$. Untuk jarak antara ruang pengawas dan ruang yang dipantau, didapatkan panjang kabel sejauh 10 m (Murisa, 2013).

Menurut Teguh, menjelaskan pada penelitian tugas akhirnya yang berjudul sistem keamanan rumah dengan menggunakan motion dan sms gateway yaitu dilakukan pembangunan sistem keamanan rumah yang berbasis opensource dan SMS Gateway dengan biaya seminim mungkin dan kirerja semaksimal mungkin. Guna menunjang keamanan tiap harinya, Tahapan awal yang ditempuh adalah mengumpulkan perangkat keras dan perangkat lunak yang dibutuhkan dalam pembangunan sistem keamanan ini. Untuk mengatasi permasalahan keamanan secara $24 \mathrm{jam}$ perhari, sistem keamanan ini sudah secara otomatis standby dan siaga selama 24 jam penuh. Untuk permasalahan informasi, sistem keamanan ini sudah berbasis SMS gateway dan report yang di keluarkan berupa SMS. Sehingga kita dapat memantau perkembangan keadaan rumah dimanapun dan kapan pun (Teguh, 2011).

Dengan beberapa kajian pustaka yang sudah dijelaskan maka penulis memilih sistem home security dengan menggunakan akses kode yang telah dirancang. Maka dirancang prototype sistem home security yang mampu memberikan sistem keamanan pada suatu rumah berdasarkan akses kode dengan alarm yang sebagai indikator dari sistem security tersebut. Sistem home security dikendalikan secara terpusat menggunakan mikrokontroler. Mikrokontroler yang digunakan adalah arduino mega yang telah diprogram menggunakan bahasa C. Penelitian ini membahas perancangan dan realisasi sistem home security, yang bagaimana arduino dapat mengatur kerja sistem home security tersebut yang dimulai pada saat pemberian akses kode dengan benar hingga pemberian akses kode yang salah.

\section{PERANCANGAN DAN REALISASI SISTEM HOME SECURITY}

\subsection{Gambaran Umum Sistem}

Pada perancangan sistem home security ini digunakan untuk memberikan segala kenyamanan, keselamatan, keamanan dan penghematan energi, yang berlangsung secara otomatis dan terprogram melalui kontroller, pada rumah sistem home security ini dititik beratkan pada sistem ini bisa bekerja pada suatu rumah yang di desain berupa prototype, sistem mampu memberikan kenyamanan serta penghematan energy pada suatu rumah dan 
sistem security mampu memberikan keamanan di rumah dari hal-hal yang tidak diinginkan sistem security ini menggunakan password untuk mengakses kedalam rumah tersebut apabila password salah maka sistem alarm yang berupa buzzer akan aktif ataupun ketika ada pergerakkan manusia ketika password belum dimasukkan maka sistem alarm akan menyala. Sistem home security ini membutuhkan kontroller yang berfungsi untuk mengontrol serta mengolah data yang selanjutnya di aplikasikan pada sistem security pada suatu rumah. Alat kontrol yang digunakan menggunakan arduino mega yang berbasis atmega 2560 dengan diprogram menggunakan bahasa $\mathrm{C}$. Kerja sistem home security yang telah dirancang dan direalisasikan diharapkan mampu bekerja sesuai dengan yang diharapkan. Berikut ini tahapan sistem yang harus dilakukan pada sistem home security.

1. Sebelum memasuki rumah terdapat kode akses yang dimana kode tersebut diprogram khusus untuk membuka pintu depan rumah

2. Apabila seseorang tidak memasukkan code sesuai yang telah diprogram dan masuk kedalam rumah secara otomasi alarm akan berbunyi.

3. Setelah memasukkan code yang sesuai dan membuka pintu limit switch akan memberikan informasi bahwa pintu terbuka secara otomatis dan kamera akan mengarah ke pintu yang berfungsi merekam kondisi saat pintu tersebut terbuka.

4. Saat seseorang masuk kedalam rumah secara otomatis lampu yang berupa led akan menyala secara otomatis karena adanya motion sensor detector.

5. Kamera akan bergerak sesuai dengan terbacanya motion sensor detector, dengan kata lain kamera akan bergerak sesuai dengan adanya pergerakan dari manusia dari satu ruangan ke ruangan lainnya.

6. Hasil kamera akan di tampilkan di komputer dan akan disimpan dikomputer yang ditempatkan secara aman.

\subsection{Perancangan dan Realisasi Perangkat Keras (Hardware)}

Spesifikasi alat sistem home security yang dirancang dan direalisasikan harus mampu melakukan beberapa proses yang dapat dilihat pada Tabel 1 .

Tabel 1. Spesifikasi sistem home security

\begin{tabular}{|c|l|}
\hline NO & \multicolumn{1}{|c|}{ Spesifikasi sistem home security } \\
\hline 1 & $\begin{array}{l}\text { Dapat mengetahui pergerakan manusia sehingga menyalakan led secara } \\
\text { otomatis sesuai dengan ruangan yang terdeteksi dengan adanya } \\
\text { pergerakan manusia tersebut }\end{array}$ \\
\hline 2 & $\begin{array}{l}\text { Dapat menghidupkan alarm yang berupa buzzer saat ssesorang masuk } \\
\text { tanpa memasukkan code pengamanan yang telah deprogram terlebih } \\
\text { dahulu. }\end{array}$ \\
\hline 3 & $\begin{array}{l}\text { Menampilan video kedalam computer saat adanya pergerakan manusia } \\
\text { sesuai dengan pergerakan manusia tersebut ke suatu ruangan. }\end{array}$ \\
\hline 4 & $\begin{array}{l}\text { Mampu menghidupkan lampu berupa led secara otomatis sesuai dengan } \\
\text { pencahayaan. }\end{array}$ \\
\hline
\end{tabular}

Berdasarkan spesifikasi sistem home security yang diinginkan, maka blok diagram sistem yang dirancang dapat dilihat seperti pada Gambar 2. 


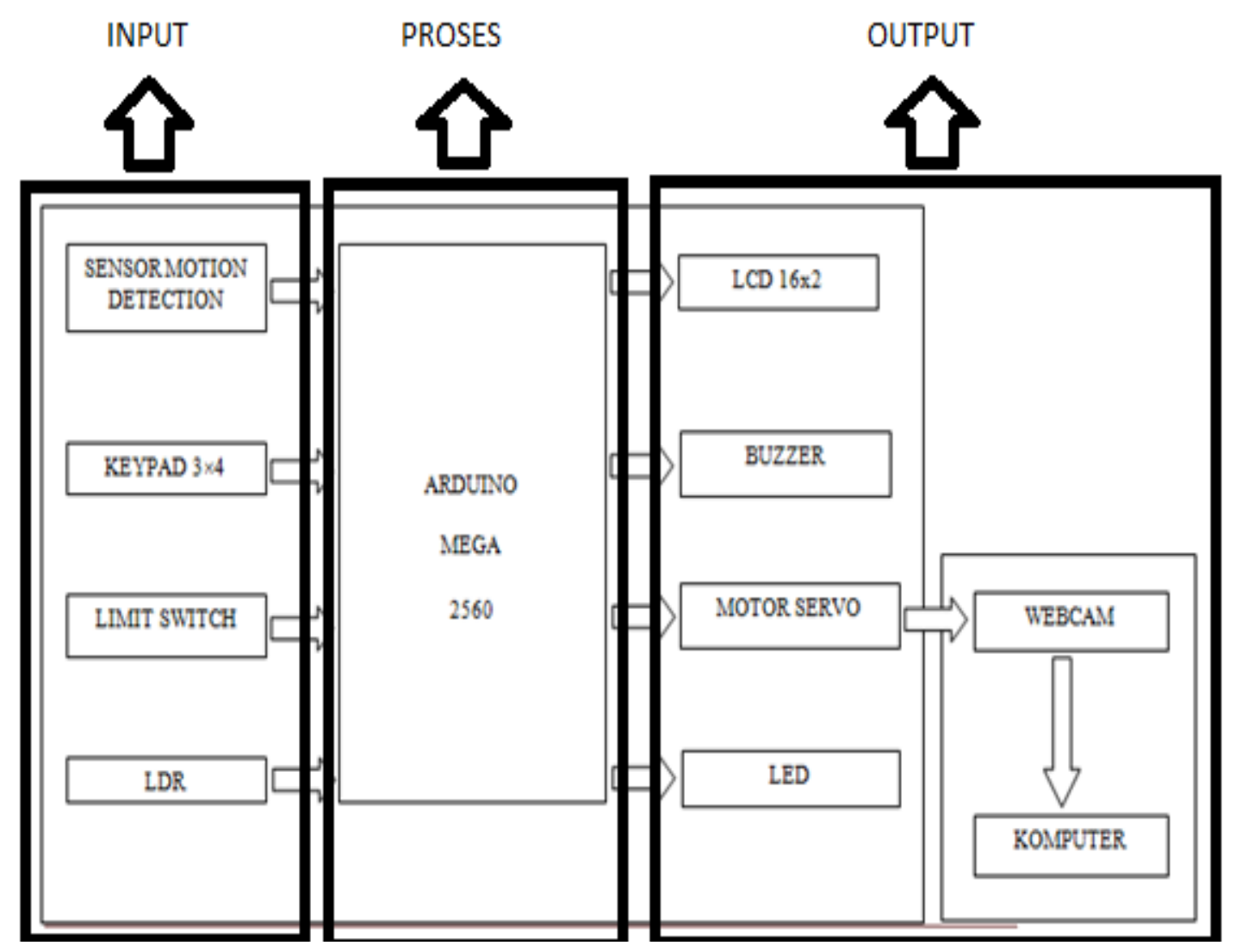

Gambar 2. Blok Diagram Sistem Home security

Berdasarkan blok diagram Gambar 2 dapat dilihat bahwa sistem home security, sistem tersebut terdiri dari 4 input dan 5 output. Berikut akan dijelaskan mengenai masing-masing fungsi dari input maupun output sistem yang dirancang berdasarkan blok diagram pada Gambar 2.

1. Keypad $3 \times 4$ berfungsi untuk mengakses kode pada sistem hom dan security sistem.

2. Motion detection berfungsi untuk mengetahui adanya pergerakan,sehingga mengaktifkan motor servo dan LED.

3. Limit switch berfungsi untuk mengetahui saat pintu terbuka atau tertutup.

4. Kamera berfungsi untuk merekam keadaan ruangan didalam ruangan.

5. Arduino Uno berfungsi untuk mengontrol dari sistem yang akan dirancang.

6. Buzzer berfungsi sebagai alarm atau penenda.

7. LED berfungsi sebagai pengganti lampu.

8. Motor servo merupakan aktuator dari kamera,untuk mengatur pergerakan kamera.

9. LCD 2x16 berfungsi untuk menampilkan akses kode yang ditekan.

10. Komputer berfungsi untuk menampilkan dan menyimpan hasil dari kamera. 
Gambar 3 merupakan realisasi dari keseluruhan perancangan perangkat keras sistem home security.

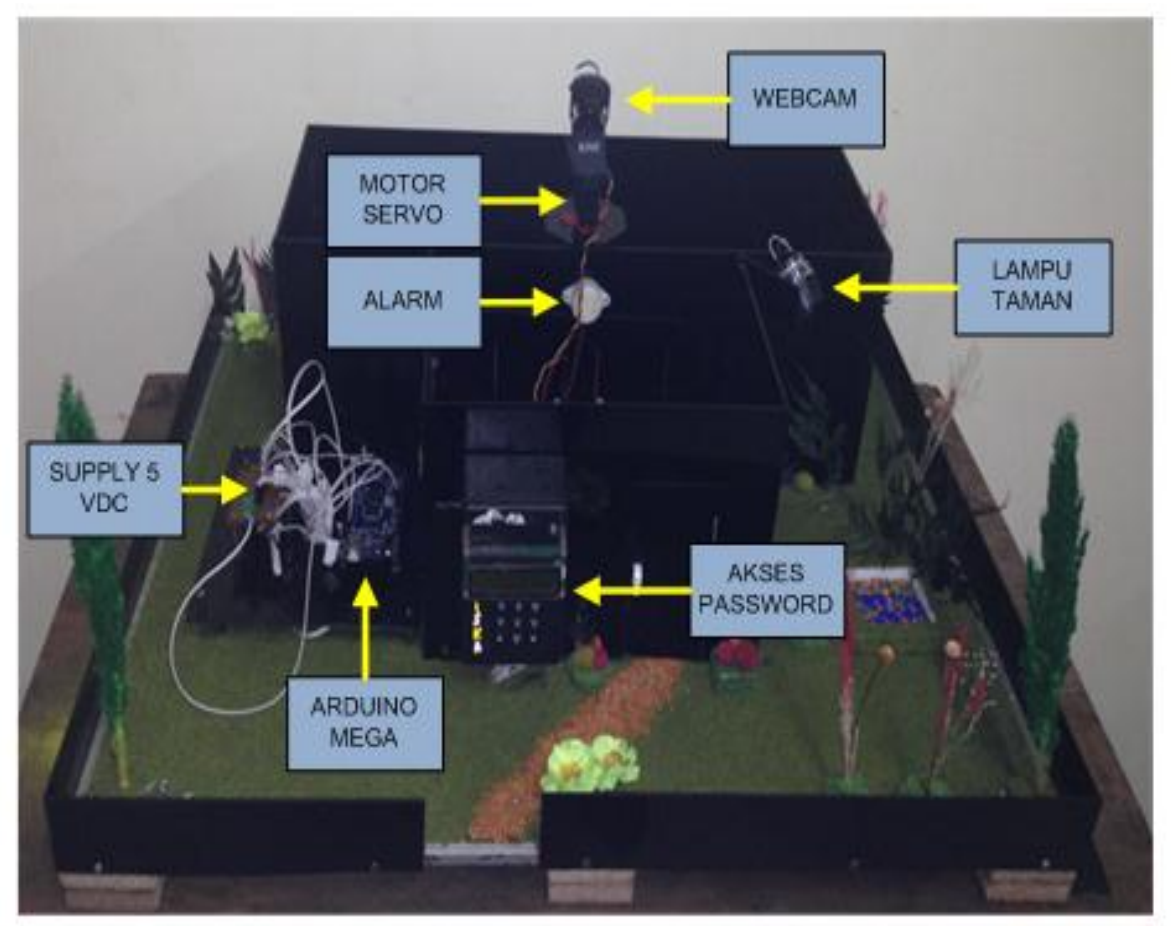

Gambar 3. Realisasi Perangkat Keras home security

\subsection{Perancangan dan Realisasi Perangkat Lunak (Software)}

Perancangan perangkat lunak (software) yang dilakukan pada penelitian ini meliputi pengaturan kerja arduino mega dalam mengontrol sistem kerja perangkat keras dari sistem home security agar bekerja sesuai dengan algoritma yang diinginkan.

Adapun perangkat lunak (software) model sistem home security ini mempunyai spesifikasi sebagai berikut :

1. Bahasa pemrograman yang digunakan adalah bahasa $\mathrm{C}$.

2. Perangkat lunak (software) yang digunakan untuk membuat program pada model sistem home security yaitu arduino IDE

Gambar 4 menunjukkan flowchart sistem home security yang dirancang untuk diubah ke dalam bentuk bahasa pemrograman. 
Implementasi Prototype Sistem Home Security dengan Pemanfaatan Kode Akses berbasis Arduino Mega

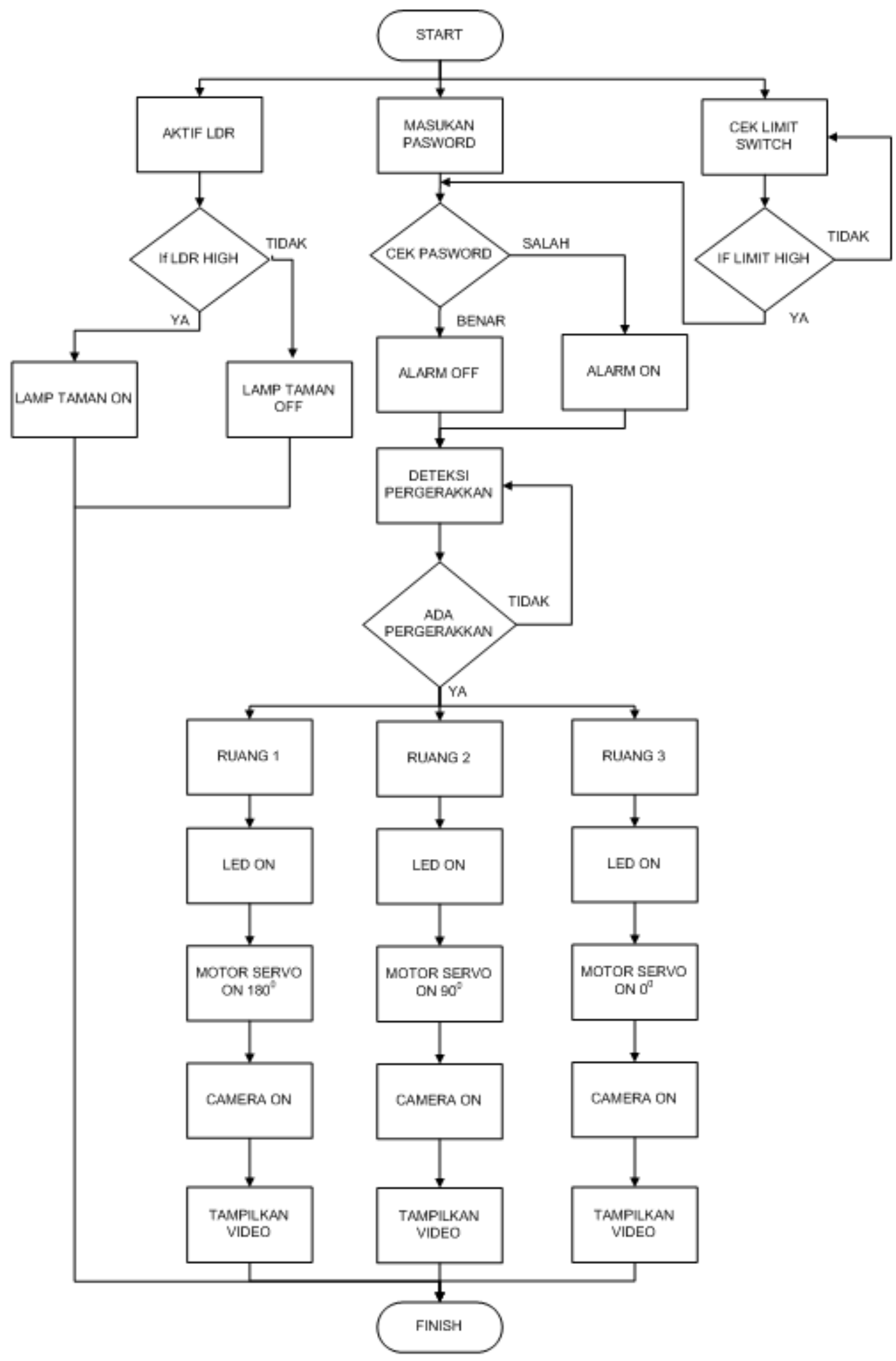

Gambar 4. Flowchart sistem home security 
Gambar 4 menunjukkan flowchart untuk sistem home security, yang dimana start adalah dimulainya sistem dengan pengecekan sensor LDR, jika sensor LDR high maka lampu taman akan menyala, akan tetapi jika sensor LDR low maka lampu taman tidak menyala. Kemudian masukkan password yang telah deprogram sebelumnya. Untuk pengecekan selanjutnya adalah pengecekan limit switch, jika limit switch 1 aktif maka pintu terbuka. Pada saat pintu terbuka maka dilakukan pengecekan password. Jika password yang dimasukkan benar maka alarm akan mati, apabila password yang dimasukkan salah maka alarm akan menyala.

Deteksi objek melalui sensor motion detection. Motion berkerja saat alarm hidup maupun mati. Jika ada pergerakkan pada ruang 1 led kan menyala dan motor servo akan bergerak $180^{\circ}$ sesuai dengan letak ruangan yang terdeteksi adanya pergerakkan serta kamera akan merekam pada ruangan 1 . Hasil rekaman ditampilkan dan disimpan ke komputer. Namun jika ada pergerakkan pada ruang 2, led akan menyala dan motor servo akan bergerak $90^{\circ}$ sesuai dengan letak ruangan yang terdeteksi adanya pergerakkan. Kamera akan merekam pada ruangan 2. Hasil rekaman ditampilkan juga dan disimpan ke komputer.

Begitu pula jika ada pergerakkan pada ruang 3, led akan menyala dan motor servo akan bergerak $0^{\circ}$ sesuai dengan letak ruangan yang terdeteksi adanya pergerakkan. Kamera akan merekam pada ruangan 3. Hasil rekaman ditampilkan dan disimpan ke komputer. Setelah itu sistem berakhir/selesai.

\section{PENGUJIAN ALAT SISTEM HOME SECURITY}

\subsection{Pengujian Perangkat Keras (Hardware) \\ 3.1.1 Pengujian Sensor Motion Detection}

Tujuan pengujian dan analisis yang dilakukan pada sensor PIR adalah untuk mendapatkan parameter tentang jarak jangkauan sensor saat mendeteksi aktifitas manusia sehingga dapat disesuaikan dengan rancangan jarak jangkauan PIR sensor pada brankas pengaman otomatis yaitu 2-30 cm. Parameter selanjutnya adalah level tegangan keluaran sensor saat mendeteksi aktfitas manusia di dalam ruangan rumah sehingga dapat memberikan logika input pada arduino mega.

Tegangan input yang dibutuhkan sensor PIR adalah 5 VDC. Pada pengujian sensor PIR, dilakukan beberapa kali percobaan dengan jarak 1-5 meter menggunakan obyek yang berbeda. Hal ini dilakukan untuk mendapatkan hasil yang maksimal terhadap respon sensor dengan obyek. Obyek yang dideteksi ada tiga jenis diantaranya manusia, tumbuhan, dan kucing. Pada masing-masing obyek, dilakukan lima kali percobaan dan hasilnya diuraikan pada Tabel 2. 
Implementasi Prototype Sistem Home Security dengan Pemanfaatan Kode Akses berbasis Arduino Mega

Tabel 2. Perbandingan Pengujian Sensor PIR Terhadap Obyek

\begin{tabular}{|c|c|c|c|c|c|}
\hline No & Jarak (M) & Obyek & $\begin{array}{c}\text { Jumlah } \\
\text { Percobaan }\end{array}$ & $\begin{array}{c}\text { Tingkat } \\
\text { Keberhasilan }\end{array}$ & $\begin{array}{c}\text { Keterangan } \\
\text { Obyek }\end{array}$ \\
\hline 1 & 1 & Manusia & 5 Kali & 5 Kali $(100 \%)$ & Mendeteksi \\
\hline 2 & 1 & Tumbuhan & 5 Kali & $(0 \%)$ & $\begin{array}{c}\text { Tidak } \\
\text { Mendeteksi }\end{array}$ \\
\hline 3 & 1 & Kucing & 5 Kali & 2 Kali (40\%) & Mendeteksi \\
\hline 4 & 4 & Manusia & 5 Kali & 5 Kali $(100 \%)$ & Mendeteksi \\
\hline 5 & 4 & Tumbuhan & 5 Kali & $(0 \%)$ & $\begin{array}{c}\text { Tidak } \\
\text { Mendeteksi }\end{array}$ \\
\hline 6 & 4 & Kucing & 5 Kali & 2 Kali $(40 \%)$ & Mendeteksi \\
\hline & \multicolumn{2}{|r|}{ Rata-rata Tingkat Keberhasilannya $=60 \%$} & \\
\hline
\end{tabular}

Dari Tabel 2 diatas dapat disimpulkan bahwa sensor PIR akan bekerja maksimal jika obyek yang dideteksi adalah manusia dengan jarak maksimal 4 meter. Sedangkan untuk binatang (kucing) tingkat keberhasilannya hanya 40\%, dan tumbuhan sama sekali tidak dapat dideteksi oleh sensor PIR. Sehingga sensor PIR dapat digunakan pada sistem home security sebagai pendeteksi aktifitas manusia di dalam ruangan rumah.

\subsubsection{Pengujian LDR (Light Dependent Resistor)}

Pengukuran dilakukan dengan mengukur tegangan basis dan mengatur tahanan LDR mendapat pembiasan cahaya pada dengan jarak yang ditentukan dengan tabel pengukuran diperlihatkan pada Tabel 3 dan dirubah ke dalam bentuk grafik yang dapat dilihat pada Gambar 6, 7, dan 8.

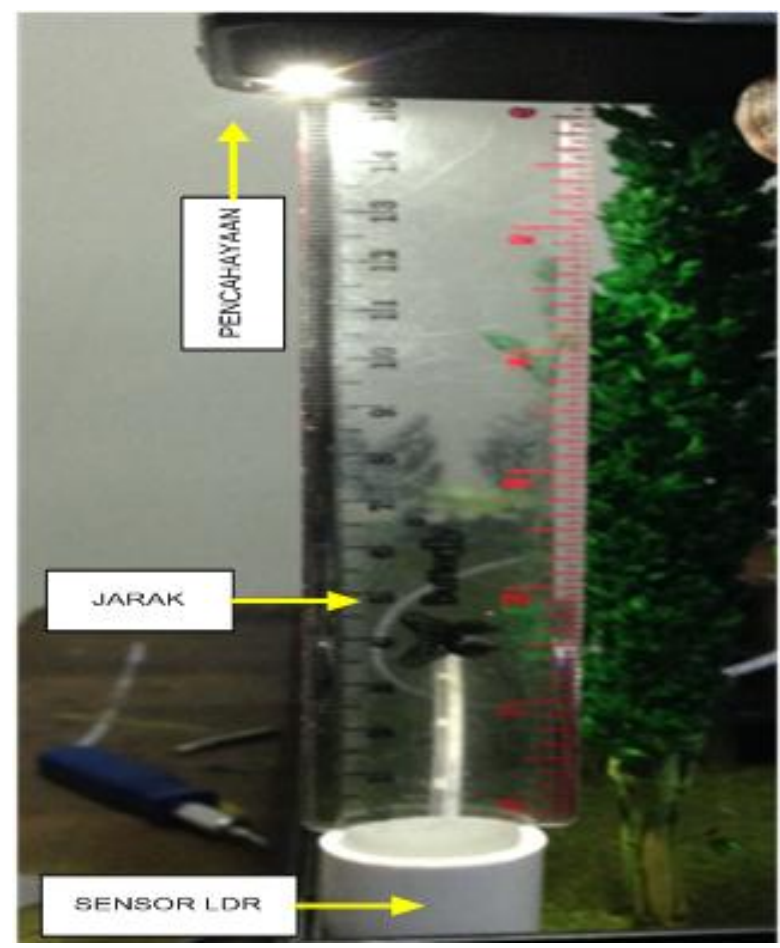

Gambar 5. Pengukuran LDR 
Tabel 3. Pengukuran Jarak LDR dan senter

\begin{tabular}{|c|c|c|c|c|}
\hline No & $\begin{array}{c}\text { Jarak Senter \& } \\
\text { LDR }(\mathrm{Cm})\end{array}$ & Tahanan LDR (Kת) & $\begin{array}{c}\text { Intensitas } \\
\text { Cahaya (Lux) }\end{array}$ & $\begin{array}{c}\text { Tegangan } \\
\text { Output (Volt) }\end{array}$ \\
\hline 1 & 3 & 0.7 & 910 & 3.4 \\
\hline 2 & 7 & 3.0 & 641 & 2.6 \\
\hline 3 & 9 & 3.6 & 234 & 2.3 \\
\hline 4 & 13 & 5.7 & 142 & 2.0 \\
\hline 5 & 15 & 7.8 & 97 & 1.6 \\
\hline 6 & 17 & 10 & 79 & 1.4 \\
\hline 7 & 22 & 19 & 66 & 1.2 \\
\hline 8 & 25 & 27 & 54 & 0.9 \\
\hline 9 & 27 & 38 & 43 & 0.5 \\
\hline 10 & 32 & 45 & 37 & 0.3 \\
\hline
\end{tabular}

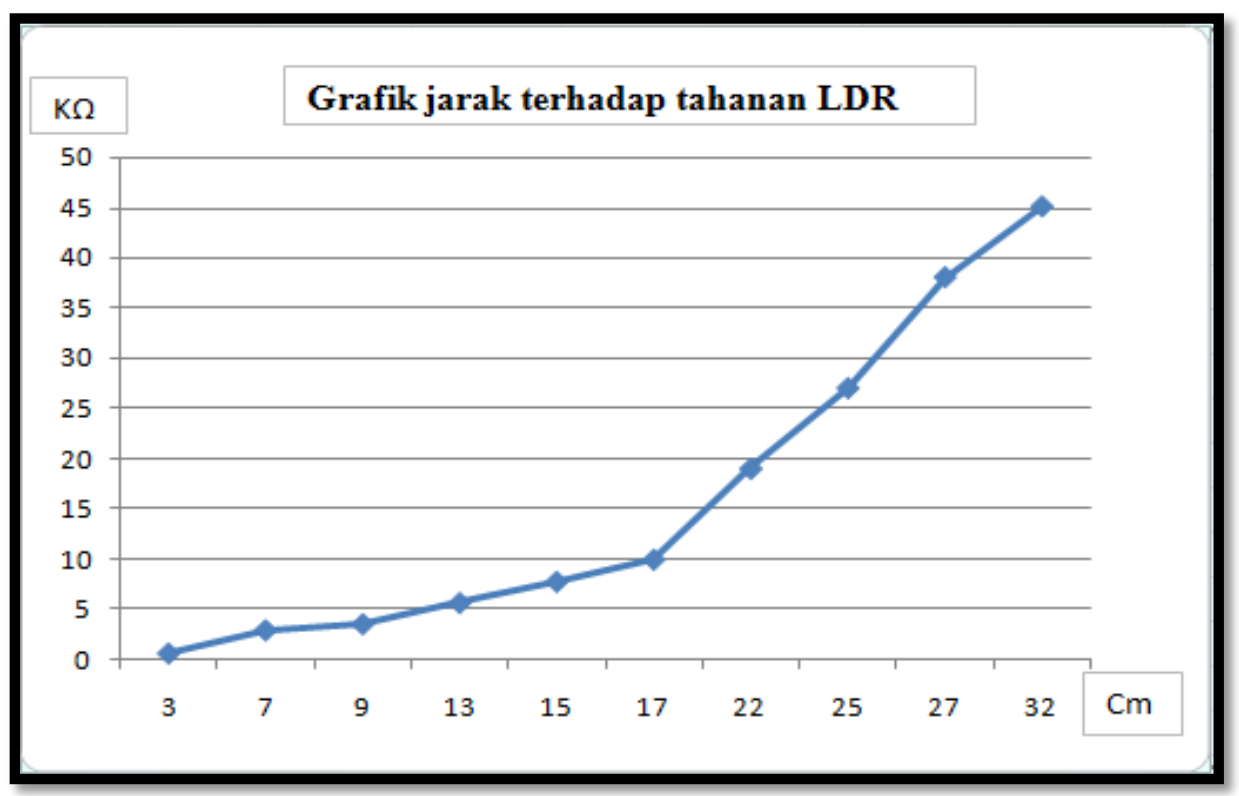

Gambar 6. Grafik Jarak Terhadap Tahanan LDR

Gambar 6 menunjukkan grafik jarak terhadap tahanan LDR yang dimana dapat dianalisis bahwa semakin jauh jarak pengukuran yang menggunakan senter maka semakin besar tahanan LDR, dan sebaliknya apabila semakin dekat jarak pengukuran maka semakin kecil tahanan LDR, hal ini disebabkan sifat LDR. 


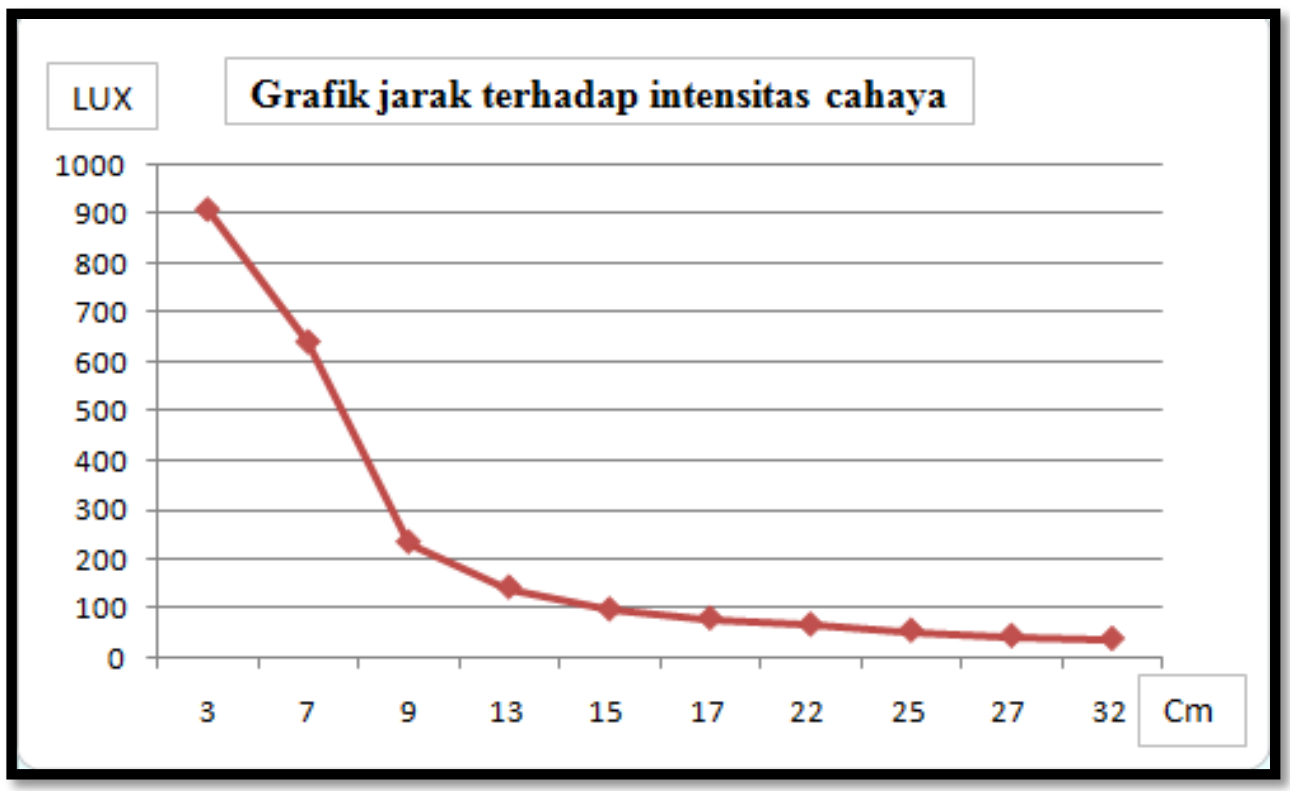

Gambar 7. Grafik Jarak Terhadap Intensitas Cahaya

Gambar 7 menunjukkan grafik jarak terhadap intensitas cahaya yang dimana dapat dianalisis bahwa semakin jauh jarak yang telah diukur maka lux semakin mengecil, dan sebaliknya apabila semakin dekat jarak yang diukur maka lux semakin membesar.

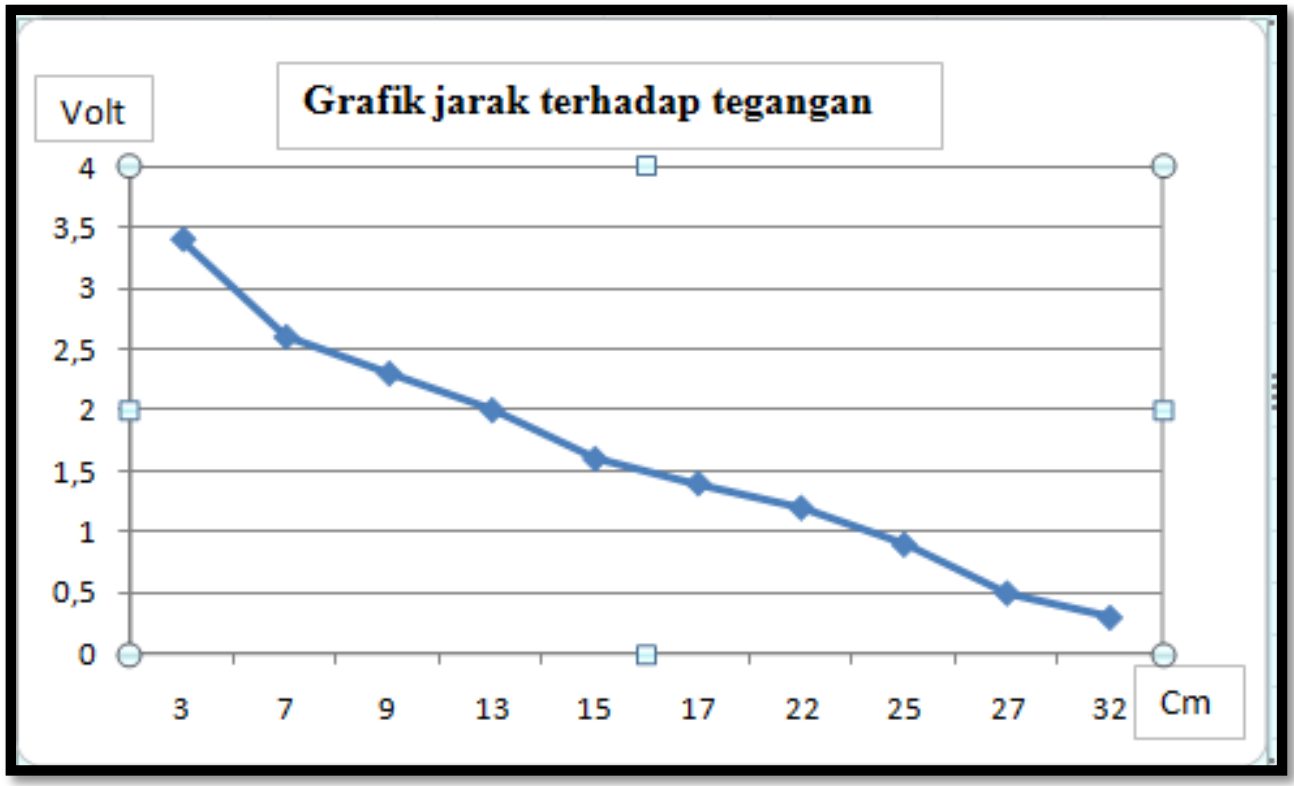

Gambar 8. Grafik Jarak Terhadap Tegangan

Gambar 8 menunjukkan grafik jarak terhadap tegangan yang dapat dianalisis bahwa semakin tinggi tingkat cahaya yang diterima oleh LDR maka tegangan output LDR akan semakin besar dan tahanan dari LDR tersebut akan semakin kecil, dan begitu pula sebaliknya jika tingkat cahaya yang diterima LDR cenderung mengecil maka tegangan output LDR akan cenderung semakin kecil dan tahanan LDR tersebut cenderung semakin besar.

\subsubsection{Pengujian Limit Switch Sensor}

Pengujian yang dilakukan pada limit switch dengan mengukur tegangan yang masuk ke dalam Arduino ketika switch tertutup (kondisi aktif). Apabila tegangan yang diperoleh ketika 
limit switch aktif adalah 5volt, maka Arduino akan membaca tegangan tersebut sebagai logic 1 sedangkan jika tegangan 0 volt maka akan terbaca sebagai logic 0 . Limit switch akan aktif jika tersentuh ujung silinder yang bergerak ke atas maupun ke bawah. Berikut ini gambar limit switch yang aktif ketika pintu tertutup. Limit switch yang digunakan ada 3, yaitu limit switch 1 sebagai indictor pintu ruangan1 ketika terbuka ataupun tertutup, limit switch 2 sebagai indictor pintu ruangan1 ketika terbuka ataupun tertutup, limit switch 3 sebagai indictor pintu ruangan1 ketika terbuka ataupun tertutup. Berikut hasil pengukuran tegangan tersebut dapat dilihat pada Tabel 4 dan Gambar 9 merupakan pengukuran limit switch pada pin arduino mega.

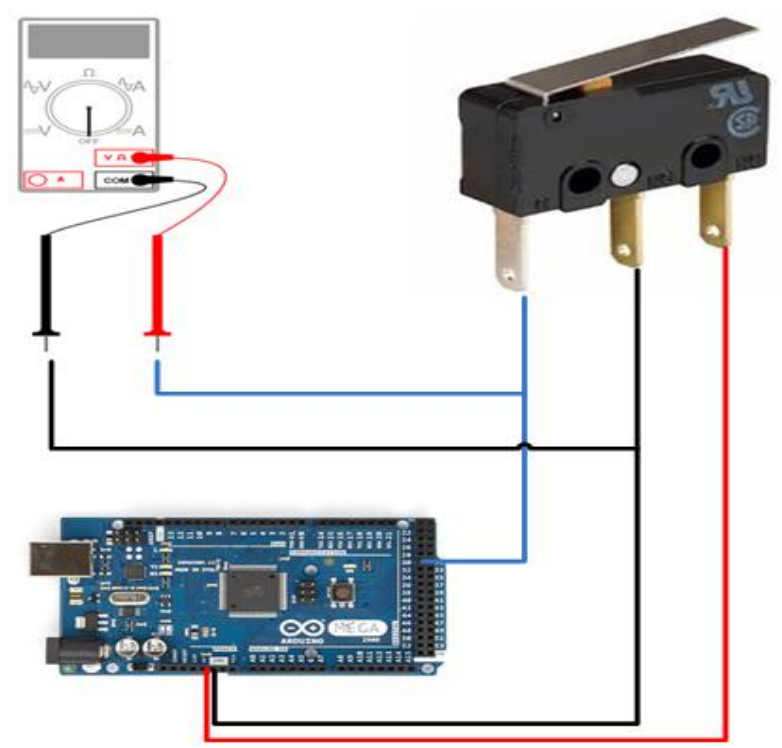

Gambar 9. Pengukuran limit switch pada pin arduino mega

Tabel 4. Pengukuran Tegangan Input Limit Switch

\begin{tabular}{|c|c|c|c|}
\hline \multirow{2}{*}{ No. } & \multirow{2}{*}{ Jenis Limit Switch } & \multicolumn{2}{|c|}{ Besar Tegangan (volt) } \\
\cline { 3 - 4 } & & Aktif & Tidak Aktif \\
\hline 1 & Limit_1 & 5,2 & 0 \\
\hline 2 & Limit_2 & 5,1 & 0 \\
\hline 3 & Limit_3 & 5,2 & 0 \\
\hline
\end{tabular}

\subsubsection{Pengujian Buzzer}

Tujuan diadakannya pengujian dan analisis kinerja buzzer adalah untuk mendapatkan parameter input tegangan pada pin input arduino mega agar dapat mengontrol tegangan masukan pada buzzer yang bekerja dengan level tegangan 5 VDC. Tabel 5 menjelaskan tentang hasil pengujian kinerja buzzer dan Gambar 10 merupakan pengukuran buzzer pada pin arduino mega dapat dilihat sebagai berikut. 


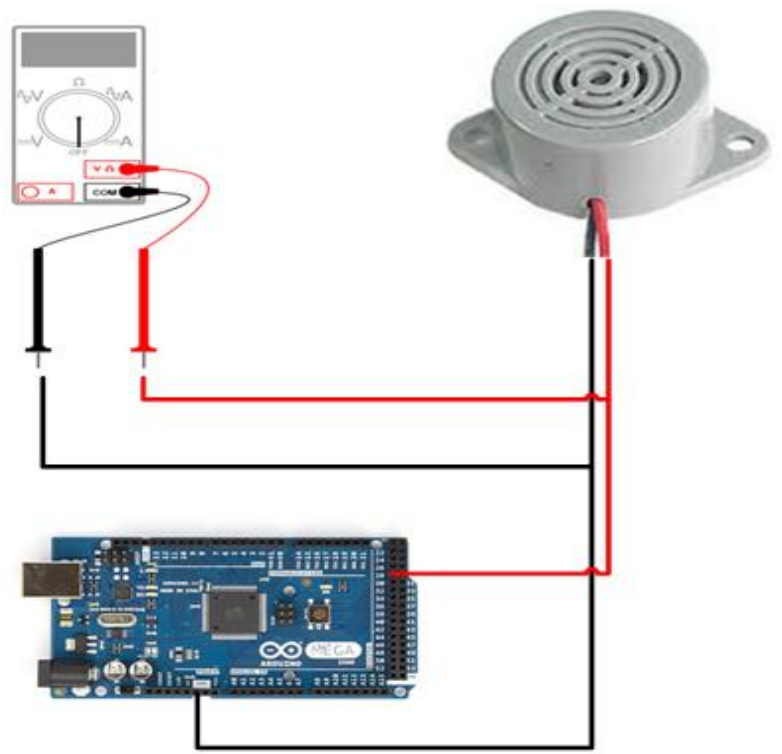

Gambar 10. Pengukuran buzzer pada pin arduino mega

Tabel 5. Hasil Pengujian Kontrol Buzzer

\begin{tabular}{|c|c|c|c|}
\hline NO & PIN ARDUINO & TEGANGAN(V) & $\begin{array}{c}\text { RESPON } \\
\text { BUZZER }\end{array}$ \\
\hline 1 & P28 & 4,90 & ON \\
\hline 2 & P28 & 0 & OFF \\
\hline
\end{tabular}

Dari pengujian yang diuraikan pada Tabel 5 maka dapat dilihat bahwa buzzer ini telah bekerja sesuai dengan yang diinginkan yaitu, bila pin P28 arduino mega diberikan logic high sebesar 4.90 Vdc maka buzzer akan aktif dan ketika diberikan logic low sebesar 0Vdc maka buzzer tidak aktif.

\subsubsection{Pengujian LED}

Rangkaian LED indicator (lampu) yang dipasang pada rangkaian kontrol elektronik home ini menggunakan common katoda dimana pin katoda dari LED dihubungkan secara langsung ke GND (OV), sehingga pengujian akan dilakukan melalui pin Arduino Mega yang diatur sebagai output dan digunakan untuk mengontrol pin anoda dari LED indikator yang dihubungkan secara seri dengan resistor sebagai pembatas arus yang masuk pada LED. Pada Tabel 6, akan dijelaskan tentang penggunaan program dan hasil eksekusinya terhadap LED indikator. Berikut Gambar 11 adalah skematik pengujian LED pada pin arduino mega. 


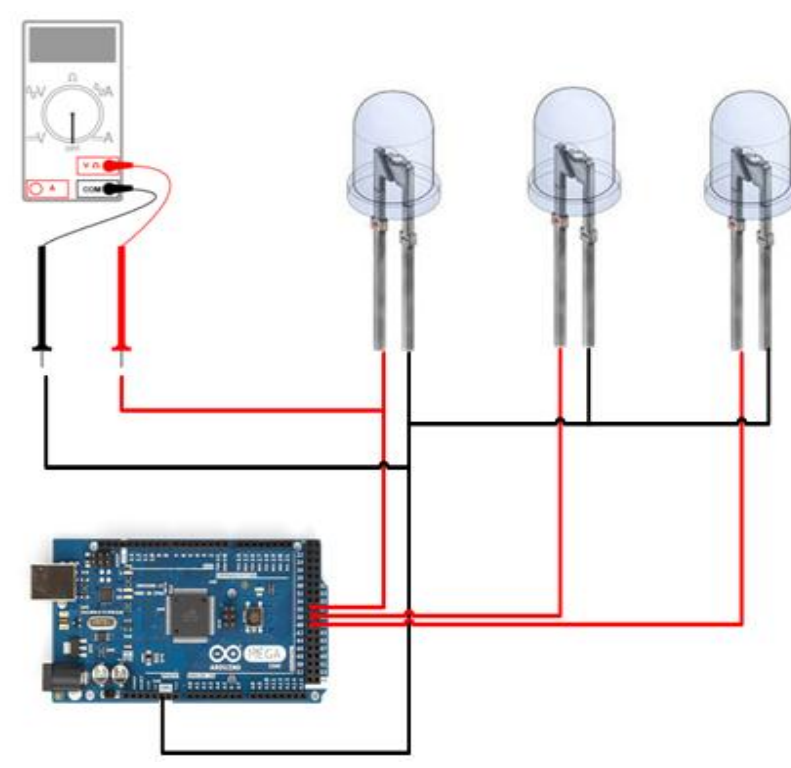

Gambar 11. Skematik pengujian LED pada pin arduino mega

Tabel 6. Hasil Pengujian LED Indikator

\begin{tabular}{|c|c|c|c|c|c|}
\hline NO & \multicolumn{3}{|c|}{ PORT LED } & OUTPUT ARDUINO & KONDISI LED \\
\cline { 1 - 3 } & LED 1 & LED 2 & LED 3 & MEGA & ON \\
\hline 1 & P36 & P38 & P40 & 4,90 & OFF \\
\hline 2 & P36 & P38 & P40 & 0 & \\
\hline
\end{tabular}

Dari pengujian LED indikator yang dilakukan, analisa yang didapat adalah bila pin P35,P38 dan P40 diset sebagai output dan melalui perintah yang berfungsi memberikan logika high pada pin tersebut, maka pada pin-pin LED, maka pada LED akan diberi tegangan 4,90 sehingga LED pada kondisi ON atau menyala, sedangkan ketika diberikan logika low pada pin-pin LED, maka LED akan diberi tegangan OV sehingga LED pada kondisi OFF atau mati (tidak menyala).

\subsubsection{Pengujian Motor Servo}

Pada pengujian motor servo dilakukan dengan menggunakan osciloscope terhubung ke pin 9 arduino mega, karena keluaran dari pin 9 arduino berupa sinyal PWM. Kemudian sinyal PWM tersebut di diberikan untuk menggerakkan motor servo sesuai yang telah di program di arduino. Pengujian motor servo dapat dilihat pada Gambar 13 dan Gambar 12 adalah blok diagram pengukuran PWM. 
Implementasi Prototype Sistem Home Security dengan Pemanfaatan Kode Akses berbasis Arduino Mega
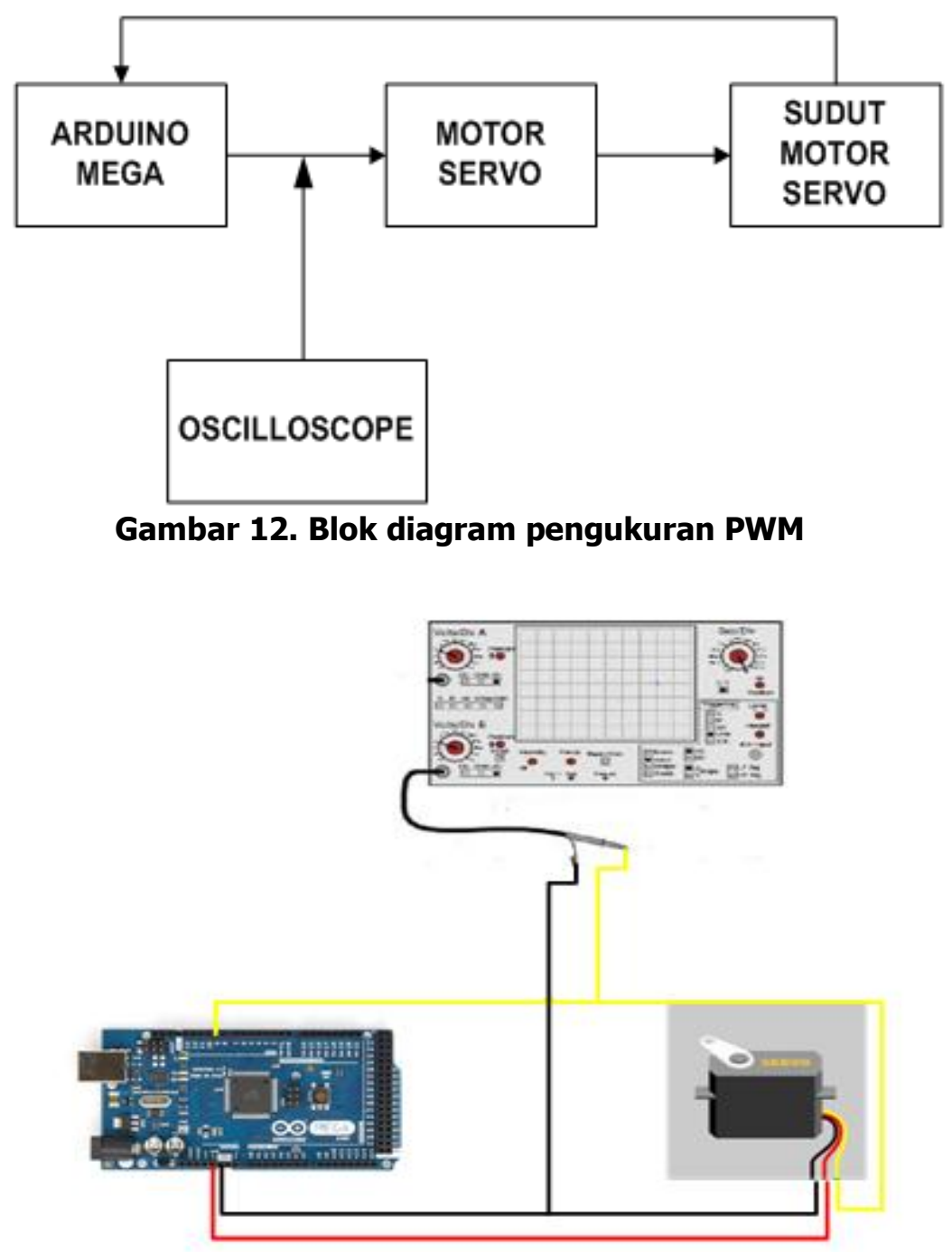

Gambar 13. Pengukuran PWM dengan oscilloscope pada pin arduino mega

Berikut pengujian motor servo yang terhubung dengan arduino mega dapat dilihat pada Tabel 7.

Tabel 7. Hasil pengujian motor servo

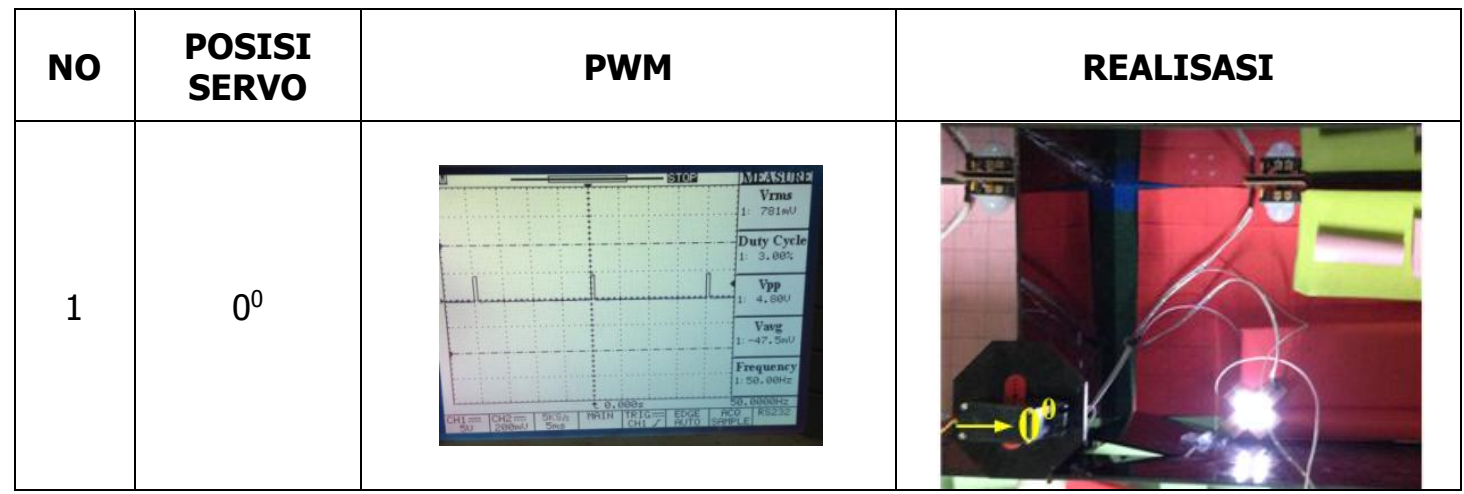




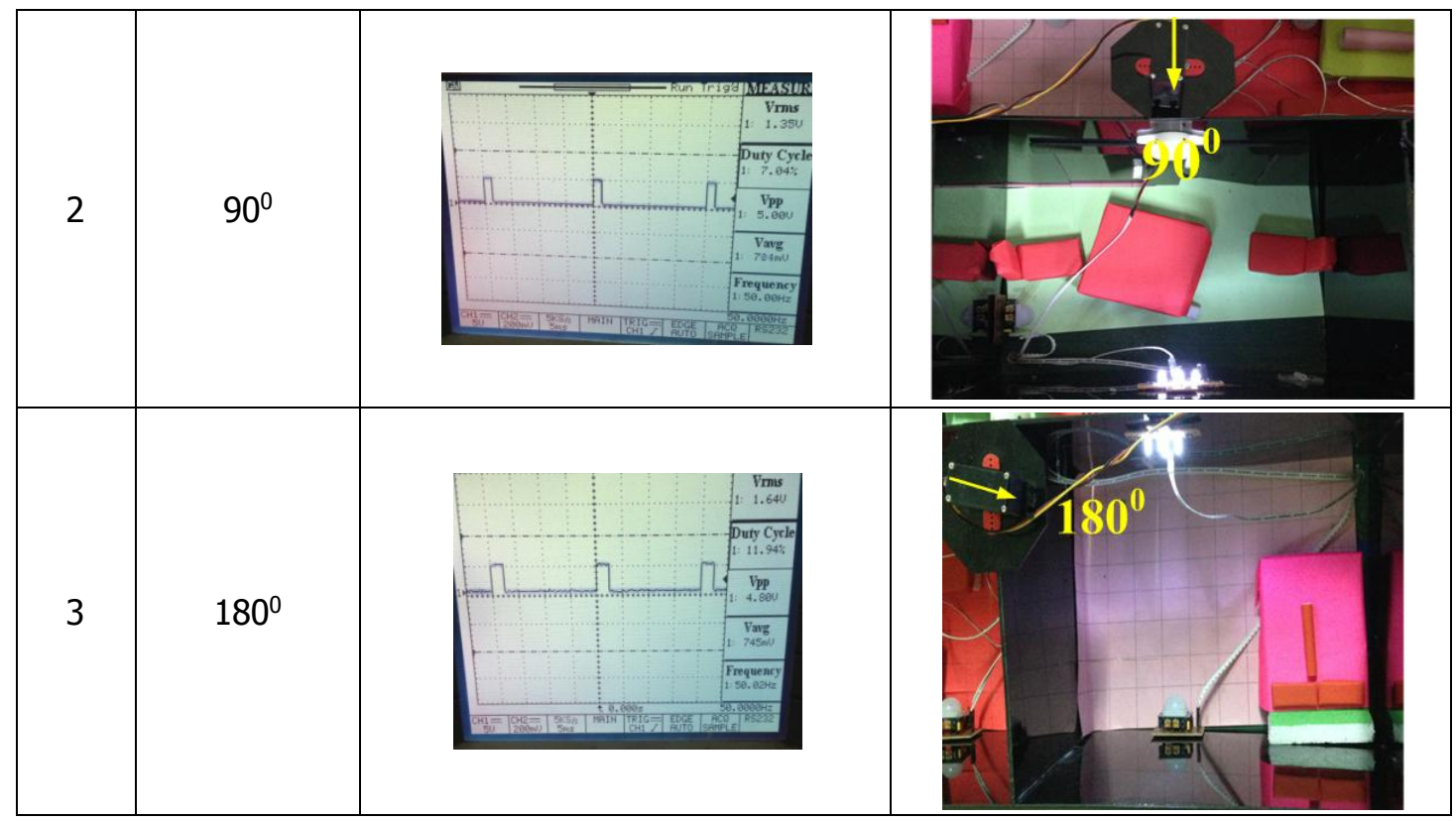

Berdasarkan hasil pengujian yang dilakukan terhadap pemberian sinyal pwm yang berasal dari kaki pin 9 arduino mega, maka dapat dilihat bahwa motor servo ini telah bekerja sesuai dengan yang diinginkan yaitu mampu bergerak dengan sudut yang diingikan $0^{\circ}, 90^{\circ}$ dan $180^{\circ}$. Adapun pada saat sudut 1800 tidak sesuai dengan sudut yang diinginkan dikarenakan gear yang berada dalam motor servo telah mengalami kerusakan.

\subsubsection{Pengujian sistem password}

Pada pengujian sistem password dengan memberikan password yang benar dan salah, pengujian sistem password dilakukan untuk mengetahui apabila password yang diberikan tidak sesuai dengan password yang sebenarnya apakah sistem password berjalan dengan baik atau tidak. Berikut pengujian sistem password yang telah diprogram dalam arduino mega dapat dilihat pada Tabel 8.

Tabel 8. Hasil pengujian sistem password

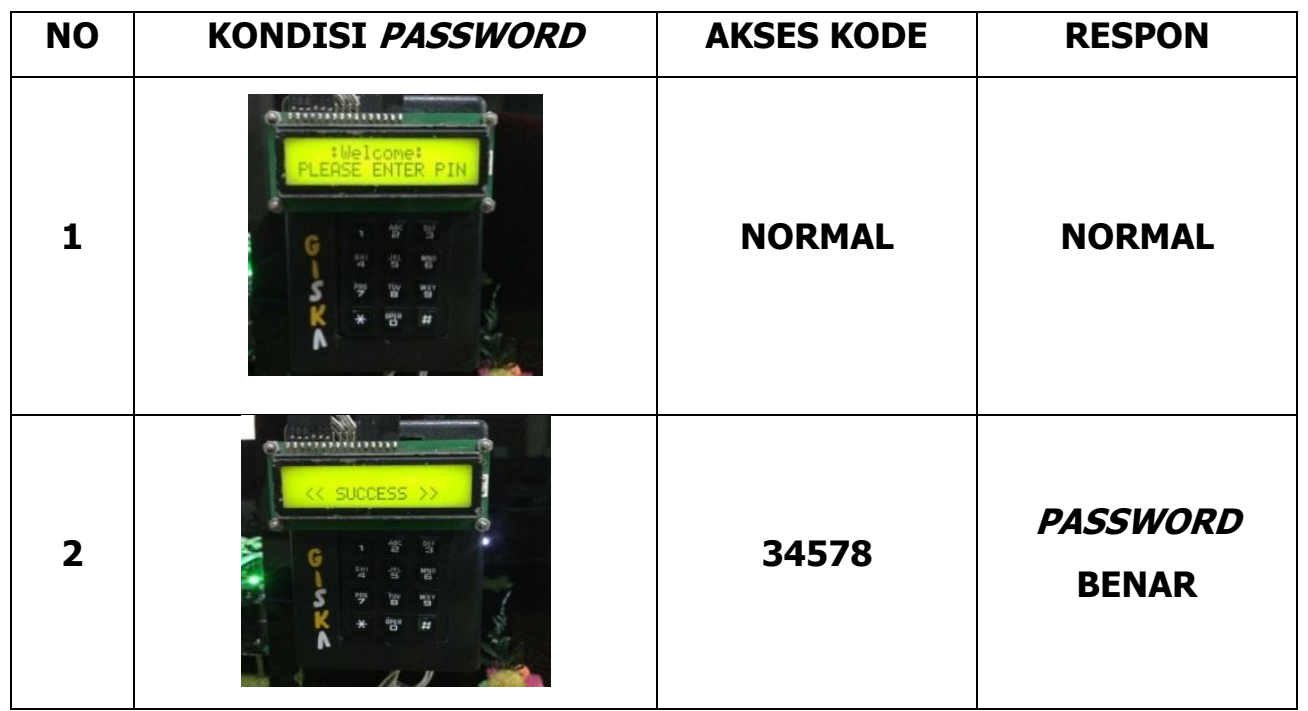




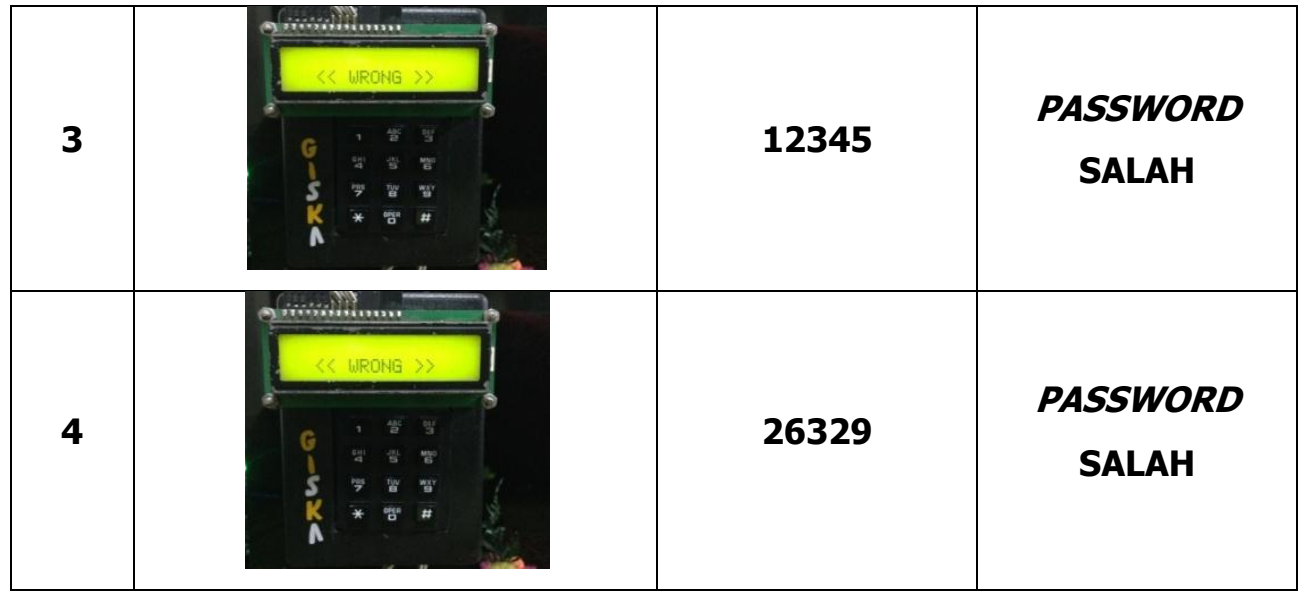

Berdasarkan hasil pengujian yang dilakukan yaitu memasukkan password dengan benar dan salah, maka dapat dilihat bahwa sistem password ini telah bekerja sesuai dengan yang diinginkan yaitu mampu mengetahui pembacaan password yang benar dan mengetahui pembacaan password yang salah. Sistem tersebut dapat dijelaskan apabila password yang benar dapat dilihat yaitu 34578 maka pintu akan terbuka.

\subsection{Pengujian Sistem Secara Keseluruhan Sistem Home security}

Setelah mengintegrasikan keseluruhan sistem, perangkat keras dan perangkat lunak, maka dilakukan pengujian terhadap sistem secara keseluruhan. Tujuan melakukan pengujian tersebut untuk melihat kinerja sistem yang dirancang secara perangkat keras (hardware) dan perangkat lunak (software) agar dapat bekerja dengan baik sesuai yang diinginkan.

Pengujian sistem dan home security secara keseluruhan yang beroperasi tiap kondisi, mulai dari kondisi normal ketika password belum diberikan, kondisi yang kedua dimana ketika password sudah diberikan akan tetapi salah, kondisi yang terakhir ketika password diberikan benar.

Berikut hasil pengujian sistem dan home security secara keseluruhan dapat dilihat pada Tabel 9.

Tabel 9. Hasil Pengujian Sistem Secara Keseluruhan

\begin{tabular}{|c|c|c|c|c|c|c|}
\hline No & Ruangan & Kondisi Pasword & Alarm & Limit & Motion & Motor Servo \\
\hline 1 & Ruangan 1 & Normal & Off & On & High & $0^{\circ}$ \\
\hline 2 & Ruangan 1 & Wrong & On & On & High & $0^{\circ}$ \\
\hline 3 & Ruangan 1 & Succes & Off & Off & High & $0^{\circ}$ \\
\hline 4 & Ruangan 2 & Normal & Off & On & High & $90^{\circ}$ \\
\hline 5 & Ruangan 2 & Wrong & On & On & High & $90^{\circ}$ \\
\hline 6 & Ruangan 2 & Succes & Off & Off & High & $90^{\circ}$ \\
\hline 7 & Ruangan 3 & Normal & Off & On & High & $180^{\circ}$ \\
\hline 8 & Ruangan 3 & Wrong & On & On & High & $180^{\circ}$ \\
\hline 9 & Ruangan 3 & Succes & Off & Off & High & $180^{\circ}$ \\
\hline
\end{tabular}

\subsection{Analisis Keseluruhan Alat Sistem Home security}

Berdasarkan hasil pengujian secara keseluruhan dapat dilihat bahwa home security sesuai dengan spesifikasi sistem home security yang dirancang dan direalisasikan mampu melakukan beberapa proses yaitu: 
Pada spesifikasi tersebut diinginkan dapat mengetahui pergerakan manusia sehingga menyalakan led secara otomatis sesuai dengan ruangan yang terdeteksi dengan adanya pergerakan masnusia tersebut. Untuk mengetahui pergerakkan manusia di tempatkan sensor PIR pada setiap ruangan sehingga apabila ada pergerakkan manusia pada ruangan maka led akan menyala pada ruangan tersebut adapun pembacaan sensor motion detection ketika adanya pergerakkan manusia diatas maket yang telah dibuat karena sensor motion detection menangkap energy panas yang dihasilkan dari pancaran sinar inframerah pasif yang dimiliki tubuh manusia yang berkisar $32^{\circ} \mathrm{C}$.

Spesifikasi sistem selanjutnya yang direalisasikan adalah dapat menghidupkan alarm yang berupa buzzer saat sesorang masuk tanpa memasukkan code pengamanan yang telah deprogram terlebih dahulu. Realisasi dari sistem dapat dilihat pada pengujian bahwa sistem alarm akan bekerja ketika seseorang masuk membuka pintu tanpa memasukkan password dan sistem alarm akan bekerja ketika seseorang memasukkan password yang salah.

Mampu memberikan informasi berupa video ke komputer saat adanya pergerakkan yang terbaca oleh sensor motion detection yang ditempatkan disetiap ruangan. Bergeraknya kamera disebabkan adanya motor servo sebagai actuator, motor servo akan bergerak sesuai dengan adanya pergerakkan disetiap ruangan. Adapun pergerakkan motor servo untuk ruangan 1 adalah $0^{\circ}$, ruangan 2 bergerak $90^{\circ}$ dan ruangan 3 bergerak $180^{\circ}$.

Spesifikasi sistem yang terakhir adalah sistem harus mampu menghidupkan lampu berupa led secara otomatis sesuai dengan pencahayaan. Lampu led di tempatkan di luar ruangan yang berfungsi sebagai lampu taman dan akan menyala apabila pencahayaan diluar rumah gelap. Untuk informasi gelap atau tidaknya pencahayaan diluar rumah menggunakan sensor LDR yang bekerja berdasarkan perubahan tahanan ,semakin tinggi tingkat cahaya yang diterima oleh LDR (Light Dependent Resistor), maka tahanan dari LDR tersebut akan semakin kecil.

\section{KESIMPULAN}

Berdasarkan hasil pengujian terhadap sistem home security menggunakan arduino mega yang telah dilakukan, maka dapat disimpulkan seperti berikut:

1. Berdasarkan hasil pengujian sistem secara keseluruhan telah sesuai dengan sistem yang diinginkan yaitu security sistem dapat bekerja dalam satu sistem yang terintegrasi, dimana saat kondisi akses kode dalam keadaan normal dan dimana tidak adanya pemberian akses kode sistem, alarm akan aktif jika pintu dari salah satu ruangan terbuka, kondisi akses selanjutnya di mana pemberian akses kode benar sistem alarm tidak aktif meskipun pintu salah satu ruangan terbuka dan kondisi yang terakhir dimana pemberian akses kode salah sistem alarm akan aktif meskipun pintu terbuka ataupun tertutup dan sistem alarm akan off jika kode akses benar.

2. Hasil pengujian sensor motion seperti pada Tabel 2 sensor PIR akan bekerja maksimal jika obyek yang dideteksi adalah manusia dengan jarak maksimal 4 meter. Sedangkan untuk binatang (kucing) keberhasilannya hanya 40\%, dan tumbuhan sama sekali tidak dapat dideteksi oleh sensor PIR. Sehingga sensor PIR dapat digunakan pada sistem home security sebagai pendeteksi aktifitas manusia di dalam ruangan rumah.

3. Berdasarkan hasil pengujian buzzer seperti pada Tabel 5 dapat dilihat bahwa buzzer ini telah bekerja sesuai dengan yang diinginkan yaitu, bila pin P28 arduino mega diberikan logic high sebesar 4.90 Vdc maka buzzer akan aktif dan ketika diberikan logic low sebesar OVdc maka buzzer tidak aktif. 
4. Integrasi antara perangkat keras dan lunak sistem home security bekerja sesuai spesifikasi sistem yang diinginkan, seperti terlihat pada hasil pengujian seluruh sistem.

5. Bergeraknya kamera disebabkan adanya motor servo sebagai actuator. Adapun pergerakkan motor servo untuk ruangan 1 adalah $0^{\circ}$, ruangan 2 bergerak $90^{\circ}$ dan ruangan 3 bergerak $180^{\circ}$.

\section{DAFTAR RUJUKAN}

Murisa. (2013). Perancangan dan Realisasi Model Sistem Monitoring Ruangan Menggunakan Webcam Berbasis Mikrokontroller ATmega16. Bandung: Murisa Pubisher.

Ardian, Johan. (2007). Perancangan dan Implementasi Sistem Penghematan Energi Untuk Pengawasan Energi Listrik Pada Smart Home. Bandung: Ardian Publisher.

Arduino. (2015). Main Software. Diakses pada 5 Juni 2015 dari http://www.arduino.cc/en/Main/Software.

Wahyudi, Teguh. (2011). Sistem Keamanan Rumah Dengan Menggunakan Motion dan SMS Gateway. Jawa Timur: Teguh Publisher.

Subari. (2015). Smart Home Sistem Pintar. Diakses pada 20 Juni 2015 dari http://subari.blogspot.com/2008/03/smart-home-sistem-pintar-di-rumah.html.

Elektronika. (2007). Buzzer. Diakses Pada 2 Agustus 2015 dari http://elektronikaelektronika.blogspot.com/2007/04/ buzzer.html

Karseno, Doni. (2011). Sistem Pengamanan Rumah Dengan Security Password Menggunakan Remote Berbasis Mikrokontroller Arduino. Yogyakarta: Doni Publisher. 